\title{
Hydromorphological Index for Rivers (HIR): A New Method for Hydromorphological Assessment and Classification for Flowing Waters in Poland
}

\author{
Krzysztof Szoszkiewicz' , Szymon Jusik', Daniel Gebler' ${ }^{1}$ Krzysztof Achtenberg', \\ Mariusz Adynkiewicz-Piragas², Artur Radecki-Pawlik², Tomasz Okruszko', \\ Marek Giełczewski ${ }^{4}$, Paweł Marcinkowski ${ }^{4}$, Karol Pietruczuk ${ }^{5}$, Marcin Przesmycki ${ }^{5}$, \\ Przemysław Nawrocki ${ }^{6}$, Joanna Chmist ${ }^{1}$, Marta Szostak ${ }^{1}$
}

1 Department of Ecology and Environmental Protection, Poznan University of Life Sciences, ul. Wojska Polskiego 28, 60-624 Poznań, Poland

2 Institute of Meteorology and Water Management - National Research Institute, ul. Podleśna 61, 01-673 Warszawa, Poland

3 Division of Structural Mechanics and Material Mechanics, Faculty of Civil Engineering, Cracow University of Technology, ul. Warszawska 24, 31-155 Kraków, Poland

4 Institute of Environmental Engineering, Warsaw University of Life Sciences, ul. Nowoursynowska 166, 02-787 Warszawa, Poland

5 Inspectorate of Environmental Protection, ul. Wawelska 52/54, 00-922 Warszawa, Poland

6 WWF Poland, ul. Usypiskowa 11, 02-386 Warszawa, Poland

* Corresponding author's e-mail: szymon.jusik@up.poznan.pl

\begin{abstract}
The method based on original metric called Hydromorphological Index for Rivers (HIR) was developed in 2017 for the purpose of the monitoring of the hydromorphological status of flowing waters in Poland. It fulfils the requirements of the EU Water Framework Directive (WFD). It allows the assessment of both lowland rivers as well as mid-altitude and highland streams. The proposed system can be used to assess the natural and heavily modified rivers as well as artificial channels. The basis of the proposed system is a field survey, which is supplemented by the analysis of Geographic Information Systems (GIS) data and remote sensing materials. The analysis of the GIS data and remote sensing materials already enable to estimate preliminary classification of the hydromorphological status of the non-surveyed water bodies. On the basis of the field survey, the principal HIR value can be estimated for the considered river site and comparing with the reference conditions, the hydromorphological quality status in the five-class system can be calculated. The properly selected, representative survey sites (one or more depending on the heterogeneity of the environment), enable the classification and evaluation of entire surface water bodies in the framework of the national environmental monitoring. The GIS component of the HIR proved to be useful in verifying the determination of heavily modified water bodies and in assessing the needs of river restoration. It was also applied in the development of the National river restoration program for predicting the impact of the proposed restoration measure on the state of hydromorphology.
\end{abstract}

Keywords: hydromorphology, rivers, streams, monitoring, surface water classification, flowing water

\section{INTRODUCTION}

The method presented in this paper is based on the original metric called Hydromorphological Index for Rivers (HIR). It was prepared in 2017 for the purpose of river monitoring in Poland (Szoszkiewicz et al. 2017). It can be used for various river types (lowland, mid-altitude and highland), including natural rivers as well as modified and even artificial channels. 
The proposed method constitutes an original system of hydromorphological assessment, which was developed based on various Polish and European methods. Many elements of the HIR method are based on the River Habitat Survey (RHS) system, which was developed in the UK (Raven et al. 1998, Boon et al. 2002, Environmental Agency 2003, Szoszkiewicz et al. 2006, Jusik et al. 2014). Moreover, significant elements of the two Polish methods were also used (Adynkiewicz-Piragas 2009, Radecki-Pawlik 2014).

The major purpose of the HIR method development was national monitoring meeting criteria of the Water Framework Directive (WFD) (European Commission, 2000) and European and Polish standard for assessing the hydromorphological features of rivers (EN 14614, 2004). The proposed method can also be utilized to predict the engineering modifications (environmental impact assessment) as well as the results of river restoration measures. Moreover, the HIR system can be used for various scientific ecological investigations of various groups of aquatic organisms.

The HIR is a field survey based method but it is supported by an analysis of the GIS data which deliver preliminary classification of hydromorphological status. Nevertheless, in the result of the field survey, the basic HIR index can be calculated for the stretch of watercourse. Comparing the HIR value with the reference conditions, the hydromorphological quality status in the five-class system can be calculated for this stretch. Representative survey sites enable for the classification of entire rivers or whole water bodies recognized by the national environmental monitoring. The final evaluation of a water body combines an average HIR value from several stretches surveyed in the field and preliminary evaluation based on the GIS data.

The process of the HIR method development is based on the original database consisting of hydromorphological survey records of 1,107 sites, carried out in the field by the authors of this paper in the period 2003-2016 (Fig. 1). This database represents full hydromorphological gradient, from the reference conditions to extreme degradation. The analysis of these data was the basis for developing a river classification method meeting the criteria of the WFD.

So far, three publications summarizing the results of the HIR method have been published - two from the Greater Poland voivodship
(Pietruczuk et al. 2019, 2020) and one from the Lower Silesian voivodship (Przesmycki et al. 2019). The GIS component of the HIR proved to be useful in verifying the determination of heavily modified water bodies and in assessing the needs of river restoration (Grela et al. 2019). It was also applied in the development of the National river restoration program, for predicting the impact of the proposed restoration measures on the state of hydromorphology (Biedroń et al. 2020).

\section{Preliminary analysis based on the GIS data}

The preliminary assessment of the hydromorphological quality of rivers is based on the commonly accessible, generally public spatial data as satellite images (e.g. Geoportal WMS service or Google Earth platform). In this way, the information supportive to field the survey was provided. Moreover, this preliminary assessment can be already utilized by the national monitoring program for the water bodies that are not considered under the field survey scheme.

Preliminary protocol considers the abundance of hydromorphological elements along the river reach or by estimation the frequency of various attributes. The analysis includes the information on hydrological regime, channel sinuosity calculated in 5 class-scale, engineering structures as water management facilities, spillways and flow regulation structures, dams, as well as bridges. Among non-engineering hydromorphological attributes the tree presence in the valley along the surveyed river reach can be recorded based on remote sensing materials.

The preliminary protocol includes several attributes of the river valley, which are analyzed in the $100 \mathrm{~m}$ wide buffer for rivers with channel width $\leq 30 \mathrm{~m}$ and whereas in the case of rivers wider than $30 \mathrm{~m}$, the buffer is $1000 \mathrm{~m}$ wide. In this way, the information on the abundance of various forms of land use is delivered, distinguishing the urban, agricultural and semi-natural form of management. Moreover, the information on the lateral connectivity of river with its valley is recorded, including the presence of embankments, interembankment zones, ox-bow lakes and wetlands. In the case of large rivers (channels $>30 \mathrm{~m}$ ), the information on the channel dimensions variability, number of bars (side bars and mid channel bars) and islands is recorded. 


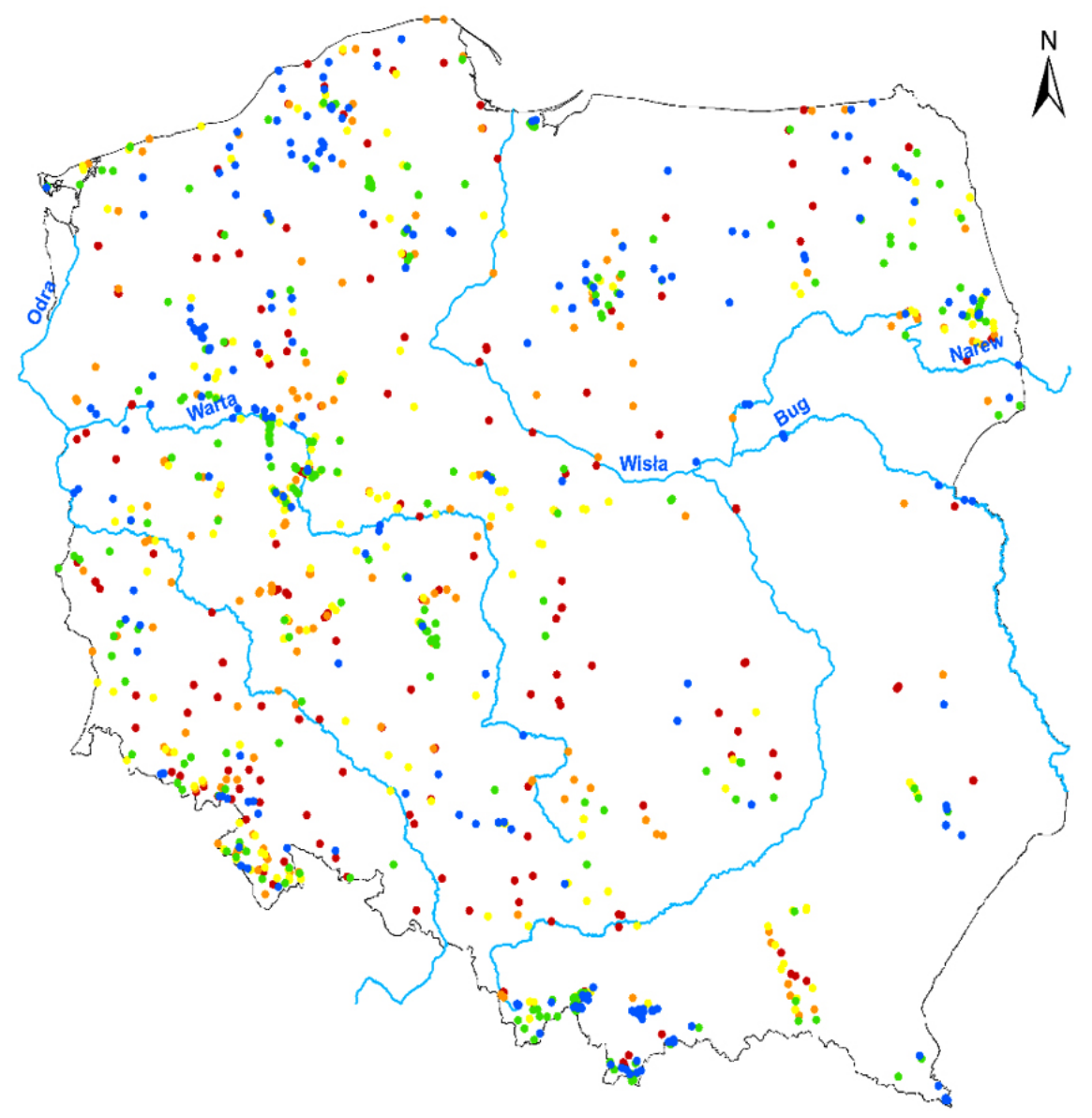

Hydromorphological state classes

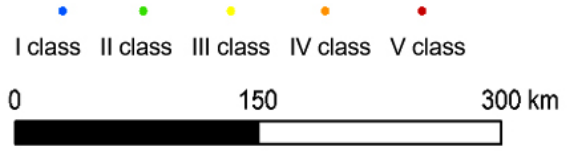

Fig. 1. The distribution of the survey sites utilized for the development of HIR method ( $\mathrm{N}=1107$ river sites). Colors indicate the classes of hydromorphology

\section{Preliminary evaluation based on the GIS data}

The preliminary assessment is based on the remote sensing materials and spatial databases. In order to assess the presence and abundance of natural elements the GIS Hydromorphological Diversity Score (GIS-HDS) was developed, whereas the GIS Hydromorphological Modification Score (GIS-HMS) informs on the degree of morphological degradation. The range of attributes considered for the GIS-HDS and GISHMS estimation is presented in Tables 1 and 2. The number of attributes included depends on the size of the rivers (number of attributes is greater in large rivers).

The preliminary evaluation of the whole river body considers GIS-HDS as well as GISWPH which are calculated on the basis of various hydromorphological attributes HDSA and HMSA:

$$
G I S-H D S=\sum H D S A_{i}
$$

where: GIS-HDS - GIS-Hydromorphological Diversity Score;

$H D S A_{i}$ - Hydromorphological Diversity Score Attributes;

$i$-attributes 1-7;

and

$$
\text { GIS-HMS }=\sum H M S A_{i}
$$

where: GIS-HMS - GIS Hydromorphological Modification Score; $H M S A_{i}$ - Hydromorphological Modification Score Attributes; $i$-attributes 1-6. 
Table 1. Attributes included in the GIS Hydromorphological Diversity Score

\begin{tabular}{|c|c|c|c|c|}
\hline Attribute symbol & Attribute name & Scale & Attribute range & Score \\
\hline \multirow{5}{*}{ HDSA1 } & \multirow{5}{*}{$\begin{array}{l}\text { Natural river route } \\
\text { (unrealigned, } \\
\text { meandering on } \\
\text { lowlands) }\end{array}$} & \multirow{5}{*}{$\%$ of the river body length } & none & 0 \\
\hline & & & $\leq 25$ & 1 \\
\hline & & & $25-50$ & 3 \\
\hline & & & $50-75$ & 5 \\
\hline & & & $>75$ & 7 \\
\hline \multirow{5}{*}{$\mathrm{HDSA}^{*}$} & \multirow{5}{*}{$\begin{array}{l}\text { Mid-channel bars and } \\
\text { islands }\end{array}$} & \multirow{5}{*}{$\%$ of the river body length } & none & 0 \\
\hline & & & $\leq 10$ & 1 \\
\hline & & & $10-30$ & 2 \\
\hline & & & $30-50$ & 3 \\
\hline & & & $>50$ & 5 \\
\hline \multirow{5}{*}{ HDSA3* } & \multirow{5}{*}{ Side bars } & \multirow{5}{*}{$\%$ of the river body length } & none & 0 \\
\hline & & & $\leq 10$ & 1 \\
\hline & & & $10-30$ & 2 \\
\hline & & & $30-50$ & 3 \\
\hline & & & $>50$ & 5 \\
\hline \multirow{3}{*}{ HDSA4** } & \multirow{3}{*}{ Floodplain land use } & \multirow{3}{*}{$\begin{array}{l}\text { Mean value based on three land use } \\
\text { categories }\end{array}$} & urban areas & 1 \\
\hline & & & agricultural areas & 5 \\
\hline & & & seminatural areas & 10 \\
\hline \multirow{5}{*}{ HDSA5 } & \multirow{5}{*}{ Woodland on bank } & \multirow{5}{*}{$\%$ of the river body length } & none & 0 \\
\hline & & & $\leq 25$ & 1 \\
\hline & & & $25-50$ & 2 \\
\hline & & & $50-75$ & 3 \\
\hline & & & $>75$ & 5 \\
\hline \multirow{5}{*}{ HDSA6 } & \multirow{5}{*}{ Oz-bow lakes } & \multirow{5}{*}{$\%$ of the river body length } & none & 0 \\
\hline & & & $\leq 10$ & 1 \\
\hline & & & $10-30$ & 2 \\
\hline & & & $30-50$ & 3 \\
\hline & & & $>50$ & 5 \\
\hline \multirow{5}{*}{ HDSA7 } & \multirow{5}{*}{ Wetlands } & \multirow{5}{*}{$\%$ of the river body length } & none & 0 \\
\hline & & & $\leq 10$ & 1 \\
\hline & & & $10-30$ & 2 \\
\hline & & & $30-50$ & 3 \\
\hline & & & $>50$ & 5 \\
\hline
\end{tabular}

* not applicable for small and medium rivers (channel $\leq 30 \mathrm{~m}$ )

** buffer width: $\leq 30 \mathrm{~m}-100 \mathrm{~m},>30 \mathrm{~m}-1000 \mathrm{~m}$

The result of evaluation based on the analysis of the GIS data enable to estimate GIS-Factor which come out from the GIS-HDS and the GIS-HMS:

GIS Factor $=\frac{\left(\frac{G I S H D S-\text { GIS HMS }}{10}\right)+1.2}{3}$

The GIS-Factor based on the remote sensing data and available spatial databases provides preliminary hydromorphological assessment of the water body, which might be a large section of a river. Moreover GIS-Factor is applied for final hydromorphological classification as a ratio influencing HIR estimated in the result of the field survey.

\section{Field survey approach}

Field survey is carried out on a standard stretch of the river with a length of $500 \mathrm{~m}$ (streams and brooks with channel width $\leq 30 \mathrm{~m}$ ) or $1000 \mathrm{~m}$ (watercourses with a channel wider than $30 \mathrm{~m}$ ).

The survey according to the HIR method includes an evaluation of three zones (Fig. 2):

- river channel - includes riverbed (permanently or partially located under water) and bank face (situated between water line and bank top);

- coastal zone - river valley adjacent to the bank top $(5 \mathrm{~m}$ wide in river width $\leq 30 \mathrm{~m}$ and $10 \mathrm{~m}$ wide in river width $>30 \mathrm{~m}$ );

- river valley - includes buffer $50 \mathrm{~m}$ (river width $\leq 30 \mathrm{~m}$ ) or $100 \mathrm{~m}$ (river width $>30 \mathrm{~m}$ ) wide adjacent to the bank top. 
Table 2. Attributes included in the GIS Hydromorphological Modification Score

\begin{tabular}{|c|c|c|c|c|c|}
\hline Attribute symbol & Attribute name & & Scale & Attribute range & Score \\
\hline \multirow{5}{*}{ HMSA1 } & \multirow{5}{*}{ Watercourse realignment } & \multirow{5}{*}{\multicolumn{2}{|c|}{$\%$ of the river body length }} & none & 0 \\
\hline & & & & $\leq 25$ & 1 \\
\hline & & & & $25-50$ & 3 \\
\hline & & & & $50-75$ & 5 \\
\hline & & & & $>75$ & 7 \\
\hline \multirow{4}{*}{ HMSA2 } & \multirow{4}{*}{ Damming structures } & \multirow{4}{*}{\multicolumn{2}{|c|}{$\%$ of the river body length }} & none & 0 \\
\hline & & & & $\leq 0,2$ & 3 \\
\hline & & & & $0,2-0,5$ & 5 \\
\hline & & & & $>0,5$ & 7 \\
\hline \multirow{4}{*}{ HMSA3 } & \multirow{4}{*}{ Water management structures } & \multirow{4}{*}{\multicolumn{2}{|c|}{$\%$ of the river body length }} & none & 0 \\
\hline & & & & $\leq 5$ & 2 \\
\hline & & & & $5-33$ & 4 \\
\hline & & & & $>33$ & 6 \\
\hline \multirow{4}{*}{ HMSA4 } & \multirow{4}{*}{ Groynes and river hydraulic structures } & \multirow{4}{*}{\multicolumn{2}{|c|}{$\%$ of the river body length }} & none & 0 \\
\hline & & & & $\leq 5$ & 1 \\
\hline & & & & $5-33$ & 2 \\
\hline & & & & $>33$ & 3 \\
\hline \multirow{4}{*}{ HMSA5 } & \multirow{4}{*}{ Bridges, fords, ferries } & \multirow{4}{*}{\multicolumn{2}{|c|}{$\begin{array}{l}\text { number/km of the river body } \\
\text { length }\end{array}$}} & $\leq 0.2$ & 0 \\
\hline & & & & $0.2-0.5$ & 1 \\
\hline & & & & $0.5-1.0$ & 2 \\
\hline & & & & $>1.0$ & 3 \\
\hline \multirow{8}{*}{ HMSA6 } & \multirow{8}{*}{$\begin{array}{l}\text { Embankments of small and medium } \\
\text { rivers (channel } \leq 30 \mathrm{~m} \text { ) } \\
\text { summarising scores for each bank }\end{array}$} & \multirow{5}{*}{\multicolumn{2}{|c|}{$\begin{array}{l}\text { embankments ( } \% \text { of the } \\
\text { river body length) }\end{array}$}} & none & 0 \\
\hline & & & & $\leq 25$ & 0,5 \\
\hline & & & & $25-50$ & 1 \\
\hline & & & & $50-75$ & 1,5 \\
\hline & & & & $>75$ & 2 \\
\hline & & \multirow{3}{*}{\multicolumn{2}{|c|}{ embanked floodplain size }} & $>2$ channel width & 0,5 \\
\hline & & & & $\leq 2$ channel width & 1 \\
\hline & & & & no floodplain & 1,5 \\
\hline \multirow{15}{*}{ HMSA6 } & \multirow{15}{*}{$\begin{array}{l}\text { Embankments of large rivers (channel } \\
>30 \mathrm{~m} \text { ) }\end{array}$} & \multirow{15}{*}{ 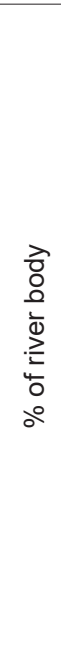 } & \multirow{5}{*}{$\begin{array}{l}\text { No floodplain between } \\
\text { embankments }\end{array}$} & none & 0 \\
\hline & & & & $\leq 25$ & 2 \\
\hline & & & & $25-50$ & 2,5 \\
\hline & & & & $50-75$ & 3 \\
\hline & & & & $>75$ & 3,5 \\
\hline & & & \multirow{5}{*}{$\begin{array}{l}\text { floodplain between } \\
\text { embankments } \leq 2 \text { of } \\
\text { channel width }\end{array}$} & none & 0 \\
\hline & & & & $\leq 25$ & 1 \\
\hline & & & & $25-50$ & 1,5 \\
\hline & & & & $50-75$ & 2 \\
\hline & & & & $>75$ & 2,5 \\
\hline & & & & none & 0 \\
\hline & & & floodplain between & $\leq 25$ & 0,5 \\
\hline & & & embankments $>2$ of & $25-50$ & 1 \\
\hline & & & channel width & $50-75$ & 1,5 \\
\hline & & & & $>75$ & 2 \\
\hline
\end{tabular}

Field observations are conducted in two stages:

- The first stage is carried out on ten spotchecks (profiles), spaced equally every $50 \mathrm{~m}$ (narrower channels $\leq 30 \mathrm{~m}$ ) or $100 \mathrm{~m}$ (wider rivers $>30 \mathrm{~m})$. The attributes recorded in each spot-check include: river bed and bank material, dominant flow type, natural habitat features as well as types of modifications. The attributes are recorded across the channel in a $1 \mathrm{~m}$ wide transect in narrower rivers $(\leq 30 \mathrm{~m})$ or $10 \mathrm{~m}$ in case of wider watercourses $(>30 \mathrm{~m})$ (Fig. 2, 3). Moreover, the structure of aquatic and bank vegetation as well as land use of a bank zone is recorded in $10 \mathrm{~m}$ wide transects. 
- The second stage is synthetic assessment of the entire river section and it delivers an overview of the entire survey site, where the natural features and modifications, which were not recorded in the previous stage (e.g. occurred between spot checks) are recorded. Moreover, a predominant valley form is described, as well as the channel dimensions and presence of hydroengineering facilities are included.

The field approach of the assessment was taken from a widely used and tested British method of hydromorphological status assessment, the River Habitat Survey, which has been tested under the Polish rivers conditions for over a decade. (Environmental Agency 2003, Szoszkiewicz et al. 2007). The hydromorphological classification of watercourses is based on Hydromorphological Index for Rivers (HIR). Multimetric HIR index combines two indices: Hydromorphological Diversity Score (HDS) and for the Habitat Modification Score (HMS). HDS informs on the presence of natural attributes of the channel, coastal zone and the river valley. Each of the HDS attributes delivers a range of points enabling to calculate HDS of the river stretch (Table 3 ). The detailed procedure of scoring is presented in the HIR method manual (Szoszkiewicz et al. 2017). HMS provides the information on the hydromorphological modifications. It includes various forms of fluvial ecosystem transformations, such as profile modifications and reinforcements and presence and abundance of engineering facilities. The HMS value is calculated by summing up the categories presented below (Table 4) although the detailed approach of scoring is provided in the original HIR manual (Szoszkiewicz et al. 2017).

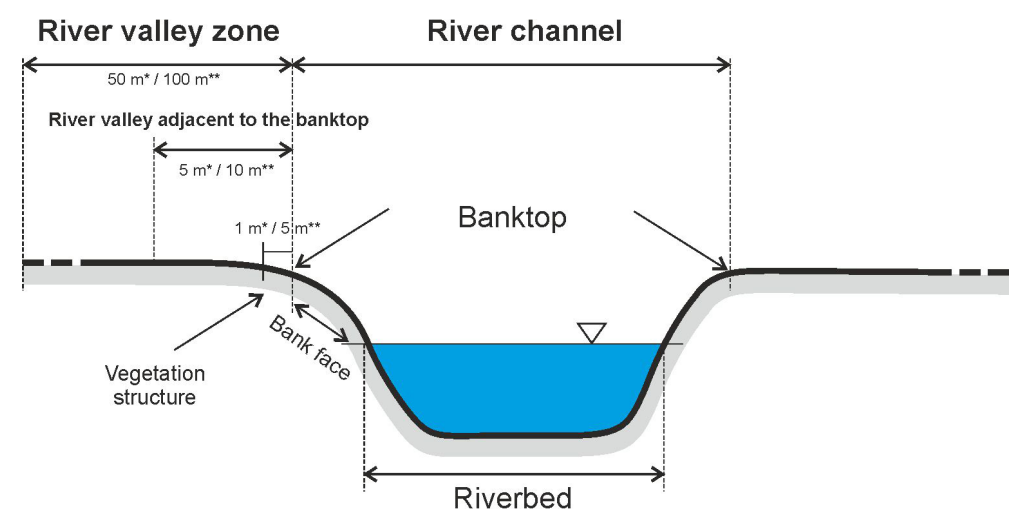

Fig. 2. Three zones in rivers evaluated in the HIR method $*$ River width $\leq 30 \mathrm{~m}$; ** River width $>30 \mathrm{~m}$ (Szoszkiewicz et al. 2017, modified)

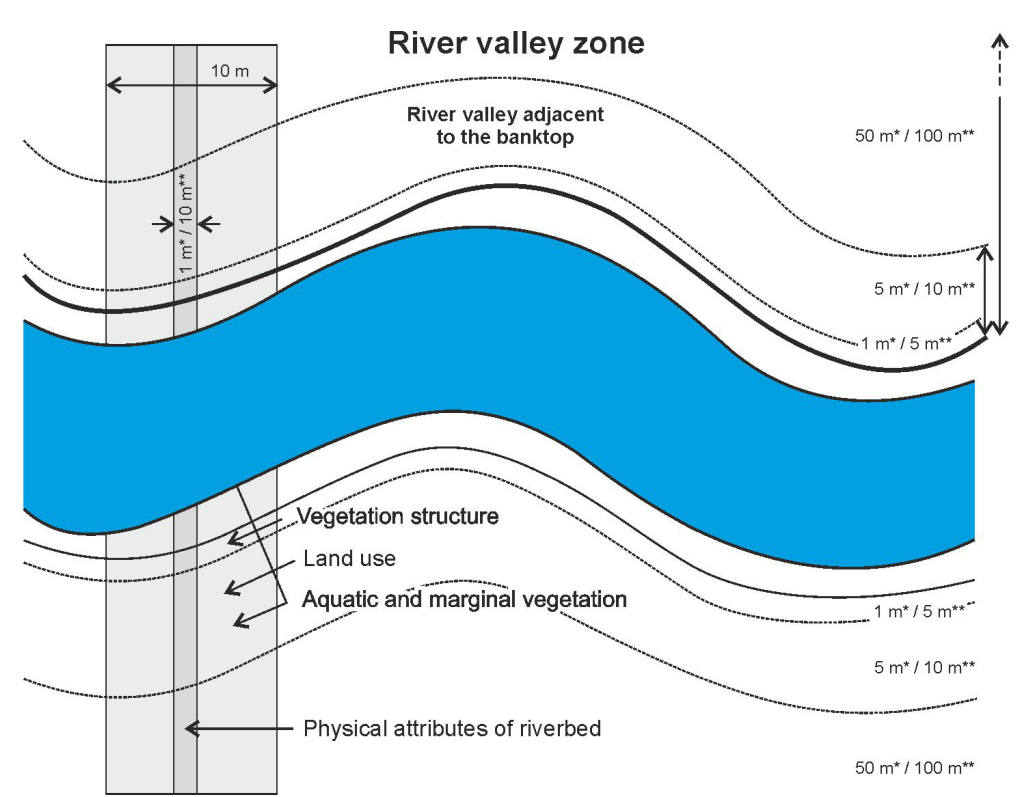

Fig. 3. Scheme of field research on single spot check *River width $\leq 30 \mathrm{~m}$; ** River width $>30 \mathrm{~m}$ (Szoszkiewicz et al. 2017, modified) 
Table 3. Attributes included in the Hydromorphological Diversity Score

\begin{tabular}{|c|c|c|}
\hline \multirow{2}{*}{ Attribute name } & \multicolumn{2}{|c|}{ Maximum score (percentage in HDS) } \\
\hline & rivers width $\leq 30 \mathrm{~m}$ & rivers width $>30 \mathrm{~m}$ \\
\hline \multicolumn{3}{|c|}{ The river channel zone - riverbed } \\
\hline Variation of the river line & $10(7.4 \%)$ & not rated \\
\hline Variation of the riverbed slope & $3(2.2 \%)$ & $3(2.8 \%)$ \\
\hline Heterogeneity of water flow & $12(8.9 \%)$ & $10(9.2 \%)$ \\
\hline Heterogeneity of rivered material & $12(8.9 \%)$ & $7(6.6 \%)$ \\
\hline Natural morphological features of riverbed & $14(10.4 \%)$ & $10(9.2 \%)$ \\
\hline Natural morphological elements of banks & $18(13.3 \%)$ & $18(16.7 \%)$ \\
\hline Variation of vegetation types in the river channel & $16(11.8 \%)$ & $14(13.0 \%)$ \\
\hline \multicolumn{3}{|c|}{ The river channel zone - bank face } \\
\hline Structure of bank vegetation & $5(3.7 \%)$ & $5(4.6 \%)$ \\
\hline Variation in elements accompanying trees & $14(10.4 \%)$ & $10(9.2 \%)$ \\
\hline \multicolumn{3}{|c|}{ The river valley adjacent to the banktop zone } \\
\hline Structure of bank-top vegetation & $5(3.7 \%)$ & $5(4.6 \%)$ \\
\hline Not-managed bank-top zone & $4(3.0 \%)$ & $4(3.7 \%)$ \\
\hline \multicolumn{3}{|c|}{ The river valley zone } \\
\hline Natural land use of the valley & $14(10.4 \%)$ & $14(13.0 \%)$ \\
\hline Connection between the river and the valley & $8(5.9 \%)$ & $8(7.4 \%)$ \\
\hline TOTAL & 135 (100\%) & $108(100 \%)$ \\
\hline
\end{tabular}

Table 4. Attributes included in the Hydromorphological Modification Score

\begin{tabular}{|l|c|c|}
\hline \multirow{2}{*}{\multicolumn{1}{|c|}{ Attribute name }} & \multicolumn{2}{c|}{ Maximum score (percentage in HMS) } \\
\cline { 2 - 3 } & rivers width $\leq 30 \mathrm{~m}$ & rivers width >30m \\
\hline Transformed transverse section of the river channel & $8(6.3 \%)$ & $8(8.7 \%)$ \\
\hline Hydroengineering structures & $30(23.8 \%)$ & $18(19.6 \%)$ \\
\hline Transformations observed in spot-checks & $60(47.6 \%)$ & $40(43.5 \%)$ \\
\hline Disturbance of the connectivity with the river valley & $12(9.5 \%)$ & $12(13.0 \%)$ \\
\hline Other types of human degradation & $16(12.8 \%)$ & $14(15.2 \%)$ \\
\hline TOTAL & $\mathbf{1 2 6 ( 1 0 0 \% )}$ & $\mathbf{9 2 ( 1 0 0 \% )}$ \\
\hline
\end{tabular}

In practice, HDS and HMS values usually does not exceed 100 .

$$
H I R=\frac{\left(\frac{H D S-H M S}{100}\right)+0.85}{1.8}
$$

\section{Rivers evaluation based on field survey}

The evaluation of a river section takes into consideration both the HDS and HMS indices. The HIR score ranges from 1 (reference conditions) to 0 (extreme degradation):

The process of reference conditions determination was carried out on the rivers that have not been subjected to significant anthropogenic pressure with apparent natural fluvial processes taking place. The principal reference criteria were as follows:

- absence or very small scale of hydromorphological modifications confirmed by low values of Hydromorphological Modification Score $(\mathrm{HMS} \leq 4)$,

- domination of natural forms of land use (forests, woodlands and bushes, tall herbs, wetlands and unvegetated open natural areas), within $50 \mathrm{~m}$ buffer from the bank top.

Both criteria were detected on 217 river sites (19.6\% of all analyzed), which were considered as reference ones. This group was used to analyze the HIR diversification among various groups of rivers in Poland and to identify the hydromorphological types of watercourses. In this way, the hydromorphological classification of the river was proposed in the five river type system (Table 5).

The HIR components form two negatively correlated gradients: HDS forms a gradient of diversity of natural morphological elements of the watercourse and river valley, while HMS is related to the gradient of anthropogenic changes in hydromorphology. The hydromorphological 
Table 5. Classification system of Polish rivers based on HIR index

\begin{tabular}{|c|c|c|c|c|c|c|c|c|c|}
\hline \multirow{2}{*}{$\begin{array}{l}\text { River } \\
\text { type }\end{array}$} & \multirow{2}{*}{$\begin{array}{c}\text { Status } \\
\text { water body }\end{array}$} & \multirow{2}{*}{$\begin{array}{c}\text { Channel } \\
\text { width }\end{array}$} & \multirow{2}{*}{ Altitude } & \multirow{2}{*}{$\begin{array}{c}\text { Valley } \\
\text { peat-bog }\end{array}$} & \multicolumn{5}{|c|}{ HIR multimetrix } \\
\hline & & & & & I & II & III & IV & $\mathbf{v}$ \\
\hline R1 & \multirow{4}{*}{ natural } & \multirow{3}{*}{$\leq 30 \mathrm{~m}$} & $>200 \mathrm{~m}$ a.s.l. & - & $\geq 0.824$ & $\geq 0.715$ & $\geq 0.600$ & $\geq 0.485$ & $<0.485$ \\
\hline R2 & & & \multirow{2}{*}{$\leq 200 \mathrm{~m}$ a.s.l. } & no & $\geq 0.761$ & $\geq 0.639$ & $\geq 0.500$ & $\geq 0.375$ & $<0.375$ \\
\hline R3 & & & & yes & $\geq 0.725$ & $\geq 0.592$ & $\geq 0.459$ & $\geq 0.326$ & $<0.326$ \\
\hline R4 & & $>30 \mathrm{~m}$ & - & - & $\geq 0.728$ & $\geq 0.613$ & $\geq 0.486$ & $\geq 0.359$ & $<0.359$ \\
\hline R5 & artificial & - & - & - & $\geq 0.513$ & $\geq 0.420$ & $\geq 0.342$ & $\geq 0.253$ & $<0.253$ \\
\hline
\end{tabular}

transformations of rivers usually lead to a decrease in the heterogeneity of the river habitat (Fig. 4).

The method of calculating the HIR components is similar to the synthetic hydromorphological indicators calculated on the basis of the RHS method (Szoszkiewicz et al. 2012). The RHS equivalent of HDS is Habitat Quality Assessment - HQA, while the RHS equivalent of HMS is also the Habitat Modification Score (Fig. 5).

\section{Water body assessment}

River assessment based on a survey of a single site delivers the information limited to the local conditions. Such information is not efficient to characterize the entire river over a distance of tens of kilometers but surveying a single site its hydromorphological quality can be estimated classification for the purpose of local monitoring. Moreover, local assessment is principal for Environmental Impact Assessment (EIA) of the planned channel modifications and various water engineering projects. The local hydromorphological data can be also used for the ecological studies of various aquatic organisms (fish, macroinvertebrates, macrophytes et al.).

The hydromorphological assessment of rivers with a length of several kilometers or tens of kilometers (e.g. entire surface water bodies) requires the field data gathered from 1-3 stretches and analysis of the GIS data. The number of recommends survey sites depends on river heterogeneity of the land use in the river valley zone and varies between one (homogenous land use) to three (large diversity of land use). Three land use categories are distinguished in this process: (1) natural/semi-natural areas, (2) agricultural land, and (3) urban localities. The considered buffer width is $100 \mathrm{~m}$ from river both banks (river width $\leq 30 \mathrm{~m}$ ) or $1000 \mathrm{~m}$ (river width $>30 \mathrm{~m}$ ). The land use category is considered when it covers at least $25 \%$ of the buffer zone area (Fig. 6).

The assessment of the hydromorphological state of the entire Water Body consists in calculating the weighted average of the HIR values, taking into account the weighting factor for three forms of land development (calculated on the

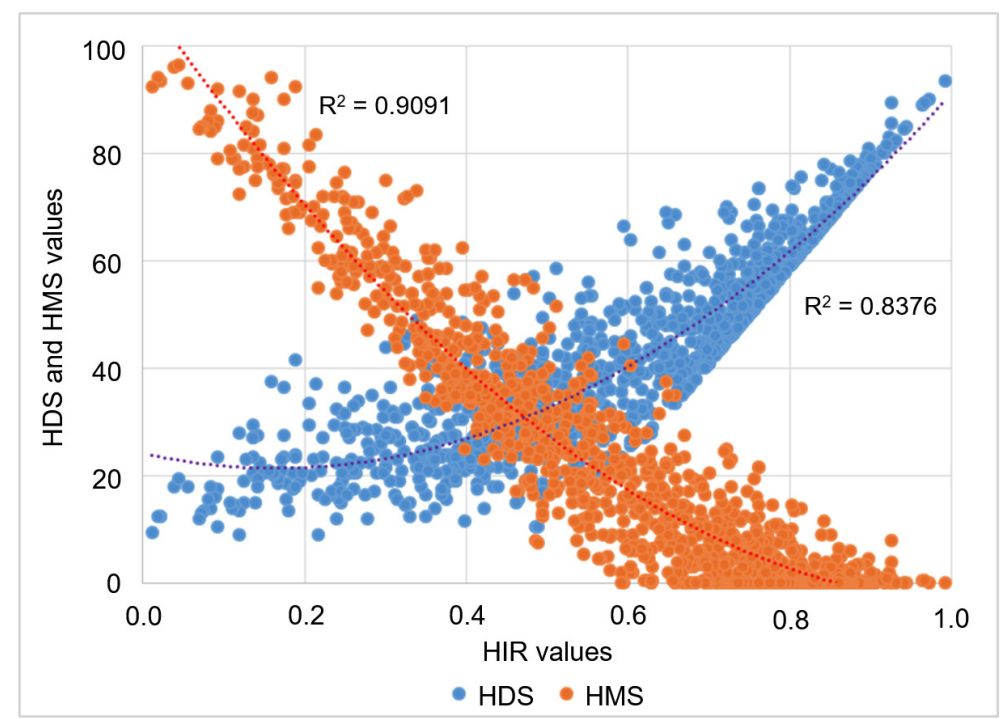

Fig. 4. Polynomial regression curves between HIR and its components - HDS and HMS (N $=1107$ river sites) 

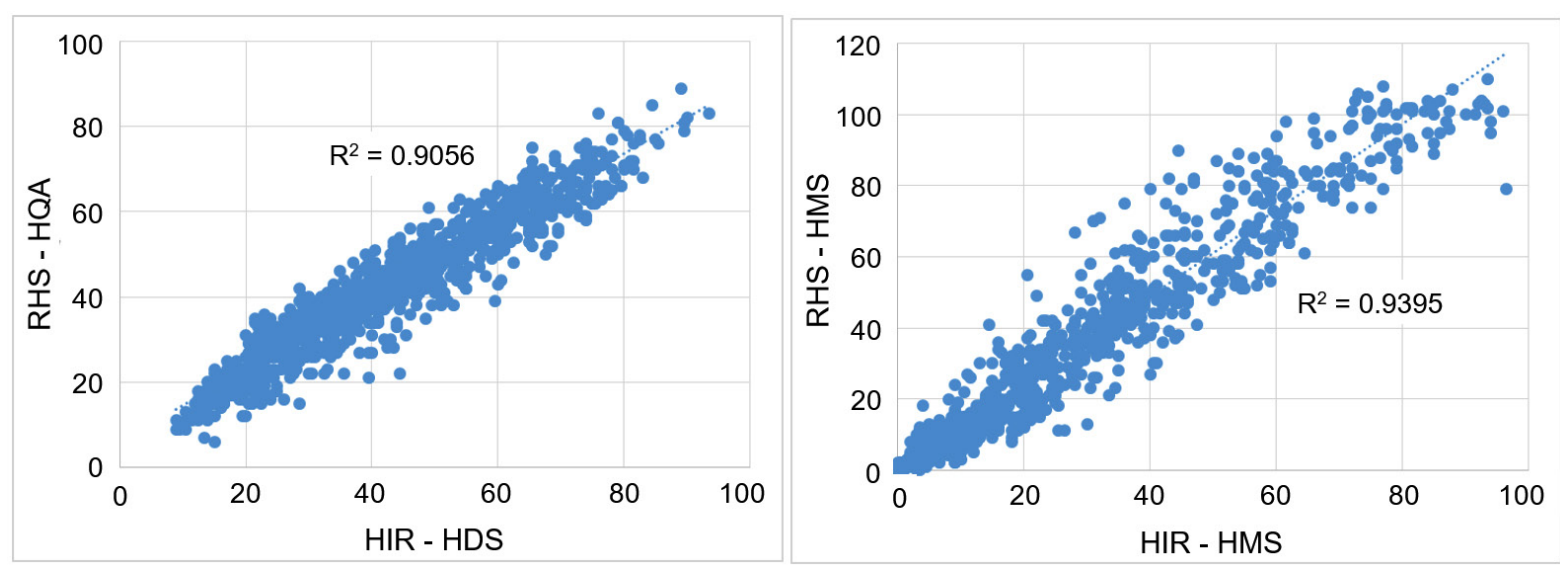

Fig. 5. Linear regression curves between indices calculated on the basis of the HIR (HDS, HMS) and RHS (HQA, HMS) methods
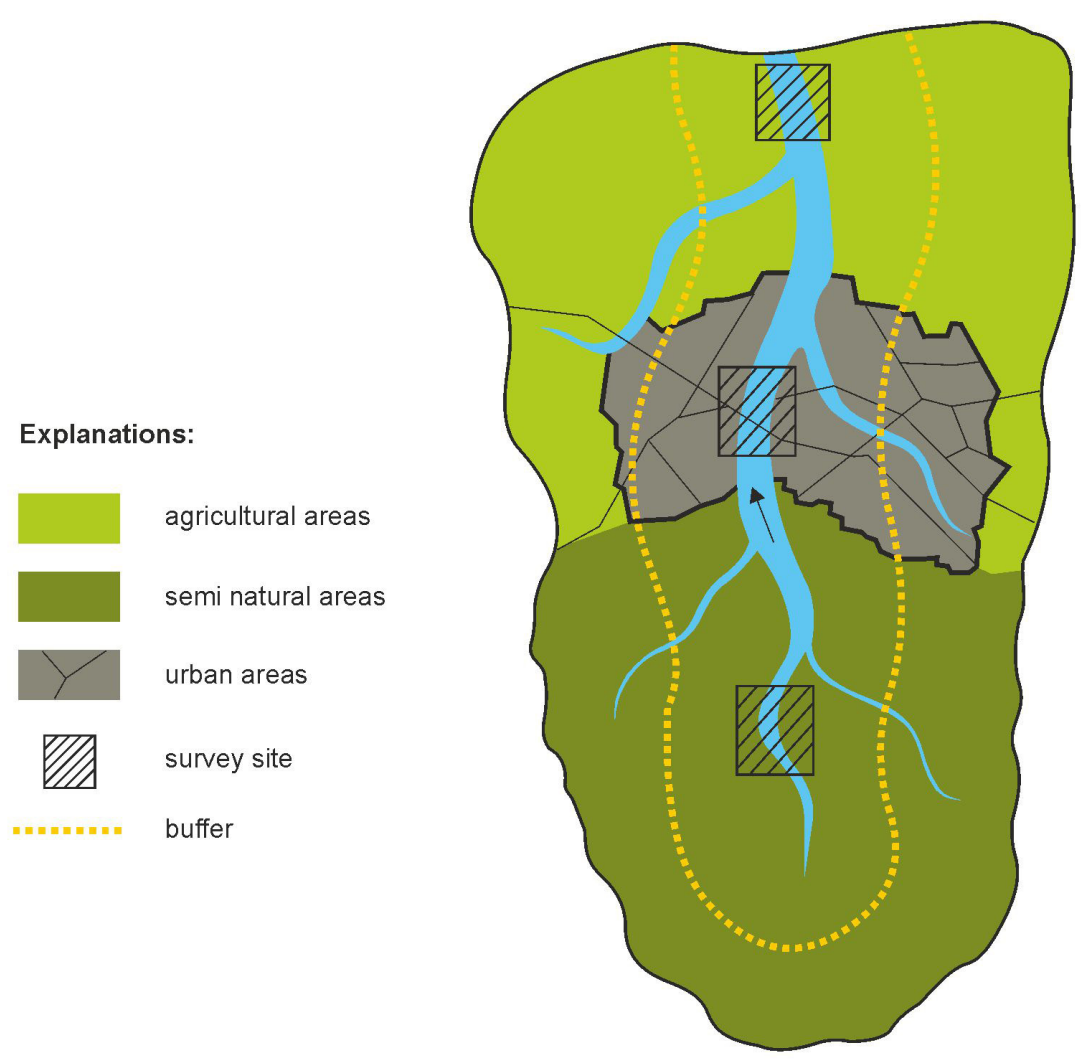

Fig. 6. Scheme of the water body survey (Szoszkiewicz et al. 2017, modified)

basis of their percentage share in the buffer), according to the following formula:

$$
\begin{gathered}
H I R_{\text {mean }}= \\
=\frac{\left(H I R_{U} \cdot w U\right)+\left(H I R_{A} \cdot w A\right)+\left(H I R_{S} \cdot w S\right)}{100}
\end{gathered}
$$

where: $H I R_{\text {mean }}-$ average HIR value for the whole water body;
$H I R_{U}$ - HIR calculated for the survey sites located in an urbanized area;

$w U$-weighting factor for urbanized areas calculated on the basis of their percentage share in the buffer;

$H I R_{A}-$ HIR calculated for the survey sites located in an agricultural area;

$w A$ - weighting factor for agricultural areas calculated on the basis of their percentage share in the buffer; 
Table 6. Impact of GIS-Factor on the final classification of the river body (HIR of the waterbody)

\begin{tabular}{|c|c|c|c|c|}
\hline \multirow{7}{*}{$\begin{array}{l}\mathrm{HIR}_{\text {mean }} \text { based } \\
\text { on the surveyed } \\
\text { stratches }\end{array}$} & \multirow{2}{*}{$H I R_{\text {mean }}$ class } & \multicolumn{3}{|c|}{ GIS-Factor } \\
\hline & & $\leq 0.4$ & $0.4-0.6$ & $>0.6$ \\
\hline & 1 & 2 & 1 & 1 \\
\hline & 2 & 3 & 2 & 1 \\
\hline & 3 & 4 & 3 & 2 \\
\hline & 4 & 5 & 4 & 3 \\
\hline & 5 & 5 & 5 & 4 \\
\hline
\end{tabular}

$H I R_{S}-H I R$ calculated for the survey sites located in a semi-natural area; $w S$ - weighting factor for semi-natural areas calculated on the basis of their percentage share in the buffer.

The hydromorphological status of entire water body base od average HIR value $\left(\mathrm{HIR}_{\text {mean }}\right)$ out of each surveyed stretch (HIR of each field surveyed site) modified by GIS-Factor (based on the preliminary assessment of remote sensing data). Average HIR is a weighted mean value based on HIR of 1-3 stretches representing proportionally various types of land use in the bank buffer along the entire surface water body. Moreover, the final classification of the water body is modified by GIS-Factor derived from on the remote sensing and spatial databases (Table 6).

\section{Acknowledgements}

The HIR method was developed in the result of support of the Chief Inspectorate for Environmental Protection on the basis of contract 25/2016/POIŚ from 2016.

Publication is funded by the Polish National Agency for Academic Exchange under the International Academic Partnerships Program from the project "Organization of the 9th International Scientific and Technical Conference entitled Environmental Engineering, Photogrammetry, Geoinformatics - Modern Technologies and Development Perspectives".

\section{REFERENCES}

1. Adynkiewicz-Piragas M., Błachuta J, Lejcuś I., Picińska-Fałtynowicz J. 2009. Pilot studies of hydromorphogolical and biological parameters of Nysa Łużycka and their tributary based on The Water Framework Directive IMGW Delegation of the Wrocław, typescript, ss. 125.

2. Biedroń I. (red.), Bogdańska-Warmuz R.,
Borzuchowska J., Brzóska P., Dondajewska R., Drożdżal E., Filipczyk J., Furdyna A., Gołdyn R., Grygoruk M., Grześkowiak A., Horska-Schwarz S., Jusik S., Krawczyk D., Krzymiński W., Krzyszczak A., Okrasiński K., Olszar M., Pawlaczyk P., Popek Z., Prus P., Szałkiewicz E., Wybraniec K., Żak J. 2020. Opracowanie krajowego programu renaturyzacji wód powierzchniowych. Kraków, ss. 137.

3. Boon P.J., Holmes N.T.H., Maitland P.S., Fozzard I.R. 2002. Developing a new version of SERCON (System for Evaluating Rivers for Conservation). Aquatic Conservation: Marine and Freshwater Ecosystems, 12(4): 439-455.

4. European Commission, 2000. Directive 2000/60/ EC of the European Parliament and of the CouncilEstablishing a Framework for Community Action in the Field of Water Policy.

5. Environment Agency 2003. River Habitat Survey in Britain and Ireland. Field Survey Guidance Manual. Environment Agency.

6. Grela J. (red.), Biedroń I., Boroń A., Gąsior M., Gebler D., Godyń I., Grzebinoga M., Grześkowiak A., Jusik S., Kokoszka R., Krawczyk D., Krzymiński W., Madej P., Mazur A., Olszar M., Pawlaczyk P., Pietruczuk K., Prus P., Stępień M., Wybraniec K., Żak J. 2019. Przegląd i weryfikacja metodyk wyznaczania silnie zmienionych i sztucznych części wód powierzchniowych wraz ze wstępnym i ostatecznym wyznaczeniem. Ostateczna metodyka wyznaczania silnie zmienionych i sztucznych części wód powierzchniowych wraz $\mathrm{z}$ koncepcją określania potencjału ekologicznego. Kraków, ss. 142.

7. Jusik S., Bryl Ł., Przesmycki M., Kasprzak M. 2014. Ewolucja metody oceny stanu hydromorfologicznego rzek RHS-PL w Polsce. Inżynieria i Ochrona Środowiska, 17 (1): 41-62.

8. Pietruczuk K., Dajewski K., Garbarczyk A., Wyrzykowska D. 2019. Zróżnicowanie warunków hydromorfologicznych wybranych rzek Wielkopolski z uwzględnieniem typologii abiotycznej i użytkowania doliny rzecznej. Woda - Środowisko - Obszary wiejskie, 19(2): 79-95.

9. Pietruczuk K., Dajewski K., Garbarczyk A., Szoszkiewicz K. 2020. Zmienność hydromorfologiczna dużej rzeki nizinnej określona w oparciu o 
Hydromorfologiczny Indeks Rzeczny (HIR) na przykładzie rzeki Warty. Inżynieria Ekologiczna, 21(2): 5-25.

10. Przesmycki M., Jusik S., Achtenberg K. 2017. Pilotażowe wdrożenie Hydromorfologicznego Indeksu Rzecznego (HIR) do oceny wód płynących w ramach Państwowego Monitoringu Środowiska (PMŚ). Przegląd Przyrodniczy, 28 (4): 201-223.

11. Radecki-Pawlik A. 2014. Hydromorphology of rivers and mountain streams - selected sections. Edition II - revised and supplemented. Uniwersytet Rolniczy w Krakowie, ss. 304.

12. Raven P.J., Boon P.J., Dawson F.H., Ferguson A.J.D. 1998. Towards an integrated Environment Agency. River Habitat Survey in Britain and Ireland - Field
Survey Guidance Manual: 2003 Version, Wielka Brytania.

13. Szoszkiewicz K., Buffagni A., Davy-Bowker J., Lesny J., Chojnicki B.H., Zbierska J., Staniszewski R., Zgola T. 2006. Occurrence and variability of River habitat Survey features across Europe and the consequences for data collection and evaluation. Hydrobiologia, 566: 267-280.

14. Szoszkiewicz K., Jusik S., Adynkiewicz-Piragas M., Gebler D., Achtenberg K., Radecki-Pawlik A., Okruszko T., Gielczewski M., Pietruczuk K., Przesmycki M., Nawrocki P. 2017. Podręcznik oceny wód płynących w oparciu o hydromorfologiczny indeks rzeczny. Biblioteka Monitoringu Środowiska, Warszawa. 